\title{
STREAMLINING MANAGEMENT SOLUTIONS FOR ECONOMIC, EFFECTIVE AND EFFICIENT SPENDING OF RESOURCES FOR SECURITY AND DEFENSE
}

\author{
Venelin Terziev ${ }^{1}$ and Nikolay Nichev ${ }^{2}$ \\ ${ }^{1}$ Professor, Ph.D., D.Sc. (National Security), D.Sc. (Ec.), University of Rousse, Rousse, Bulgaria; \\ National Military University, Veliko Tarnovo, Bulgaria; University of Telecommunications and Post, \\ Sofia, Bulgaria, terziev@skmat.com \\ ${ }^{2}$ Colonel Associate Professor, Ph.D., National Military University, Veliko Tarnovo, Bulgaria, \\ nicheff@gmail.com
}

\begin{abstract}
The paper makes analyses of the role of financial provision in the strategic management of the resources in the security and defense system of the Republic of Bulgaria as a country part of the EU and NATO. The main thesis is that the management of defense and security system should be treated as an economic activity, i.e. in accordance with the principles of the market orientation and effectiveness. The issues of effectiveness and efficiency are scrutinized in the context of financial management and the use of resources in the whole system. Main conclusions focus on the need of assuring security and defense as a public good by new operational capabilities adequate to the dynamically changing environment.
\end{abstract}

Keywords: financial provision, defense capabilities, resources management

\section{INTRODUCTION}

Strategic decisions what defense capabilities needs in response to the dynamic changes in the security environment have a direct relationship with the question "how much?" - What is the price that taxpayers should pay for the creation and development of these capabilities? And since security and defense are a public good the creation of which is entirely depending on the economic potential of the created GDP of the country, the manifestation of the price of that good is the budget of the Ministry of Defense. This makes necessary the implementation of an appropriate system and means of management of budgetary resources, by which to bring to an increase the added value of defense capabilities. That means also the application of 
the project approach and techniques (2016). It comes to financial management, which gives an answer to the sources, the planning and control of the effective spending of budgetary resources for security and defense (2011).

Put another way, the financial management system of the Ministry of Defense is a manifestation of the interaction of the management and resource provision subsystems in an organization.

The management subsystem is related to strategic decisions on achieving the targeted capabilities and their future viability in the dynamically changing security environment. Hence the establishment and maintenance of uniform set of forces and defense capabilities is a strategic objective of MF (military forces). This means building flexible and expeditionary units, capable of performing tasks in the full spectrum of missions and operations, equipped with modern technological equipment, supported by integrated logistics, capable of operating in a network-type environment, interoperable with allies troops and forces, with highly trained professional staff, to be financially secured and in compliance with the principles of economic viability in the management of resources for security and defense (2013).

In accordance to that the objective of the presented scientific research has been set, namely - studying the role of financial provision for streamlining management solutions for economic, effective and efficient spending of resources for security and defense.

\section{PRINCIPLES OF FINANCIAL PROVISION OF THE MILITARY FORCES}

Starting point of the financial provision of the military forces is a system of financial management in the Ministry of Defense, which should ensure the effective management of resources for security and defense, by fulfilling its functions, giving an idea of its elements.

The elements of the financial management system cover the processes of planning the budget by individual programs and by paragraphs of the Unified Budget Classification (UBC), the ongoing management of the budget through the year, the management of payments through the System for Electronic Budget Payments (SEBRA) the management of investment costs and cost of material and technical supply during the accounting year, accounting and analysis, and financial management and control (2014).

Depending on the powers of officers allocating budgetary credits, the responsibilities and obligations in the allocation and management of budgetary resources and increasing cost-effectiveness, the System for financial management in MoD operates on three levels.

At the first level stays the Minister of Defense, as senior budgetary credits allocating officer, assisted by the Planning, Programming and Budget and Finance directorates. The function of the Minister of Defense, as primary budgetary credits allocating officer on organizing the processes of planning, programming and budgeting defense resources, shall be carried out by the Director of Planning, Programming and Budget directorate. The functions of budget implementation and execution of payments as well as the current budget implementation according to the State Budget Act are carried out by the Director of Finance directorate.

On the second level stay the secondary budget allocating officers to the Minister of Defense, appointed by a Decree of the Council of Ministers (CoM) and the third level comprises the budget allocating officers of a lower level, such as military units.

The mechanisms of budgetary funding of the secondary budget allocating officers and the operations of the MF in accordance with the mission, their objectives and tasks, are determined annually by Budgetary Guidelines for spending the budget.

According to the doctrine of financial provision, a major source of financial resources for the activities in the field of defense is the state budget and other sources provided by law or act of the MoD. Other sources comprise own income, target funds, regulated by decisions of the Parliament and normative acts of the Council of Ministers, and programs with external financing or foreign participation (2015).

In accordance with the mission and tasks of the MF, financial provision is subject to certain rules and logic. The fundamental principles of the financial provision of defense capabilities development are: integrated defense, sufficiency of defense resources, prioritization of their spending, compatibility and modularity of the existing military formations, effectiveness, relevance and efficiency in planning and programming defense resources, continuity and consistency, comprehensiveness, avoidance of duplication, transparency in the allocation and spending of defense resources, correlation between defense capabilities and budgetary resources. Observance of those principles is the basis of a balance between the needs for defense capabilities, the economic potential and capabilities of the country, and from here - the available defense resources, focus and comprehensiveness, consistency, prioritization, predictability and multi-variability of planning, efficiency and transparency in planning and spending, hierarchy, continuous management and 
IJASOS- International E-Journal of Advances in Social Sciences, Vol. III, Issue 8, August 2017

control, analysis and evaluation of risks and threats. These also constitute the main functions of the financial management of the Ministry of Defense, based on the planning, programming and budgeting. Since the completion of the three missions of the MF is in direct connection with defense resources, their prediction and securing is the basis for the preparation of the Strategic Action Plans of MF (SAPMF), Permanent Defense Plan (PDP) Emergency Plan (EP). Their development takes place in peacetime, while an integral part of them constitutes Annex FF - Financial Provision with its annexes FF-1- Funds Provision and FF-2Contracts Conclusion.

Financial provision of the operations of the MF on mission Defense is in accordance with the planned resources for the defense programs of the MoD, the structures directly subordinated to the Minister of Defense and Bulgarian Army for a six-year period, specified in the annual budgets of the Ministry of Defense.

Financial provision of the operations of MF on mission Support for the International Peace and Security, is done through planning, construction and maintenance of Necessary Operative Capabilities (NOC) of the declared to NATO and EU military units for participation in missions and operations outside the country within the frame of defense programs of MoD, the structures directly subordinated to the Minister of Defense and Bulgarian Army, consistent with the principles of the EU and NATO. This means that the sources of financial resources for the acquisition of military capabilities of NATO are the following $(2013,2014)$ :

$\checkmark$ national financing;

$\checkmark$ multinational financing, expressed in arrangements outside the NATO bodies, between two or more Member States on international cooperation projects and on joint acquisition of skills, as an expression of „smart defense”;

$\checkmark$ co-financing, which is a special kind of multinational financing pursuant to regulating documents of NATO, under which participating countries have defined the requirements, priorities and participation share. This financing is done under the political and financial oversight of NATO, which ensures its transparency (on this basis is organized the financing of the programs of NATO for early warning and control of air - AWACS, for Alliance Ground Surveillance - AGS, to acquire capabilities for strategic air transport SAC, C-17);

$\checkmark$ common financing, which is applied in cases where the acquisition of military capabilities cannot be financially provisioned through the above mechanisms, which requires financing to be provided by share contributions of Member States through the formation of funds for common funding of NATO. It comes to the financing of NATO headquarters and the headquarters of the military command structure of NATO, the Command and Control system, the requirements to achieve interoperability in the planning and conduct of operations, and for planning and conducting exercises. Sources of common financing are civilian budgets, military budgets, the NATO Security Investment program. Common funding is realized under pre-approved spending limits for the year, pre-approved share contributions, while each type has its own rules and procedures for financial management and the management of each type is executed by a different committee representing the parties providing financial resources. Thus common funding contributes to the cohesion of NATO, ensuring its military capabilities, priorities and observance of its requirements and not least it complements national funding. Eligibility criteria for common funding are the presence of a valid military requirement and financial eligibility of the necessary capacity within the spending limits. Thus common funding puts the focus on those capabilities, the funding of which is over and above those ensured through national funding. It provides adaptability and speed of the capabilities required in crisis management. It allows maximum use of national military, civilian and NATO infrastructure facilities. Through it the military requirements are brought in line with the objectives and priorities of NATO's Strategic Concept, the Concept of minimum requirements for capabilities. Conditions are created for financial provision of essential critical military requirements, stemming from regional risk factors and strategic interests of NATO. Using common funds for financing is done on criteria set by the Board on Policy and Resource Planning of NATO;

$\checkmark$ coalition of the willing parties, which serves to finance specific activities, described in the program memorandum or in a project plan, defining the specific roles and responsibilities of the parties involved;

$\checkmark$ national contribution, which is expressed in the participation of Member States with non-financial resources (infrastructure facilities, personnel, means of communication and information services, etc.);

$\checkmark$ trust funds, used for management of voluntary financial contributions for a particular cause, thus allowing for the participation of countries which are not members of NATO.

Noteworthy is the diversity of forms and ways of accumulating financial resources for NATO operations, in direct relation to which are the operations on mission Support for International Peace, which is determined by the diversity of these operations and the strategic objectives and priorities of NATO. This requires compliance with the general principles of financing of NATO operations, stemming from the fundamental 
principle "Costs lie where they fall”. Put another way, this means the cost to be borne by those who caused them, while the common funding is focused on covering the cost of the deployed on the combat theatre staffs, and the critically important for the strategic theater infrastructure (roads, ports, airports, railway transport, etc.) (2013). It should be taken into consideration that the common funding of NATO operations does not allow for a financial provision of state-building and building of state institutions. It is not a means for solving problems in the generation of forces and resources.

The administration, management and financing of the common costs of EU operations and the creation of capabilities for rapid response and capabilities for humanitarian and rescue operations, is carried out through the so-called ATHENA, mechanism, whose annual budget for operations (aside from the contributions of the Member States in a rate approved by the Committee of the GDP of the country) is approved by a committee of representatives of the Member States. The panning and conduct of rapid response operations is carried out through an Early Financing System. Generated costs for the participation of military units of the Member States of EU in operations and missions of the EU, are at the expense of the sending nation (2013).

Planning, building and maintenance of the necessary defense capabilities of modular military formations in the composition of the various types of MF for activities on mission Contributing to National Security in Peacetime are provisioned in terms of resources by the defense programs of MoD structures directly subordinated to the Minister of Defense and Armed Forces. Reimbursement for MF participation in such operations is in accordance with the Rules of Organization and Procedure of the Inter-ministerial Commission for Recovery and Support to the COM.

The activities and tasks of the mobilization and defense training within state bodies and budget organizations are financed from the state budget, while those carried out in the municipalities- within the delegated by the state funds under the Defense and Security function- and from other sources, provided in law or act of the COM.

Financial provision of the activities and tasks on defense-mobilization and preparation of legal entities (LE) with wartime tasks are made through budgets of the respective primary budget spending allocators under contract relationship with LE.

Financial planning is carried out after prior consultation with the MoD, depending on the priorities before the start of the annual budgetary procedure.

The financial provision of activities for determining the wartime needs of the country for military and civil production and services, the assignment of wartime tasks, developing plans and programs in peacetime, is made from the state budget, respectively from the funds for the delegated by state defense activities carried out by municipalities. If provided by a legislative act or an act of the Council of Ministers, the financing may be taken from other sources. In wartime the provision of funds is made by the wartime budget of the country in accordance with the methodology for preparing and implementing the wartime budget and the budgetary guidance to public authorities, local governing bodies and local administration (2015).

Noteworthy is the diversity of sources of financial provision for the execution of the mission and the objectives and tasks of the military forces. Their economical, effective and efficient spending is directly dependent on the effective interaction between bodies and structures at different levels, which is the basis for streamlining the management of resources for security and defense.

\section{CONCLUSION}

Without claiming to be exhaustive in the study of the problems, we believe that best practices of financial management in the public sector constitute the basis for management of security and defense resources in accordance with the principles of the market orientation of behavior. This by itself is in support of the thesis that management of defense should be treated as an economic activity whose specifics lie in the functioning of the Integrated System for Defense Resources Management, as part of the System for Development of the Military Forces, based on program-objective approach to resource provision of the capabilities objectives. Moreover, such an approach is in response to the allocation of budgetary resources according to agreed priorities and defense policy of a country.

On the other side stays the economical and effective use of these resources and the civilian control of which and how much of taxpayers' resources shall be used for the public good security and defense of the country and the acquisition of the needed by the MF new operational capabilities adequate to the dynamic changes in the security environment. 


\section{REFERENCES LIST}

Arabska, E. (2016). Project management, Academic publishing house „Talent” - Plovdiv,

Athena - financing security and defence military operations:

http://www.consilium.europa.eu/en/policies/athena/.

Dimitrova, S. (2011) Management of Defense Resources in the Security Sector, Vasil Levski National Military University - Veliko Tarnovo, Bulgaria.

Dimitrova, S. Management of Resources in a Dynamically Changing Security Environment, Primaks - Ruse, (2014).

Dimitrova, S., Terziev, V. (2015). Financial provisioning - basic of strategic decisions of the management of resources for security and defence, 21th International Conference Knowledge-Based Organization, „Nicolae Balescu” Land Forces Academy, Publishing House Sibiu, The Knowledge-Based Organization, 11-13 lunie, Vol.XXI, N2.

Doctrine of financial provision (NP-8), declared with Order of the Minister of Defense of the Republic of Bulgaria No.OX-83 from 05.02.2013. (2013). 